\title{
Chromolaena odorata (Siam weed) in eastern Africa: distribution and socio-ecological impacts
}

\author{
Ross T. Shackleton · Arne B. R. Witt • Winnie Nunda $\cdot$ David M. Richardson
}

Received: 30 July 2016/ Accepted: 18 November 2016/Published online: 23 November 2016

(C) Springer International Publishing Switzerland 2016

\begin{abstract}
Invasive alien plant species such as Chromolaena odorata have negative impacts on biodiversity, ecosystem services and human well-being. Ecological impacts of this shrub are relatively well understood, but its impacts on local livelihoods and perceptions are poorly documented. We mapped $C$. odorata distribution in eastern Africa (Ethiopia, Kenya, Rwanda, Tanzania and Uganda) and compared perceptions and quantified the impacts of this species across Tanzanian villages with varying degrees of invasion density. Data were collected through 240 household questionnaires. Results indicate that $C$. odorata is a relatively new invader that already has severe negative impacts and is threatening livelihoods and the environment. Impacts include reductions in native biodiversity and the amount of available forage for livestock, reduced crop and water yields, and impaired mobility. Continued spread will cause
\end{abstract}

R. T. Shackleton · D. M. Richardson

Department of Botany and Zoology, Centre for Invasion Biology, Stellenbosch University, Matieland 7602, South Africa

e-mail: rtshackleton@gmail.com

D. M. Richardson

e-mail: rich@sun.ac.za

A. B. R. Witt $(\varangle) \cdot$ W. Nunda

CABI Africa, PO Box 633-00621, Nairobi, Kenya

e-mail: a.witt@cabi.org

W. Nunda

e-mail: w.nunda@cabi.org additional negative impacts on poor rural communities. Implementation of a biological control programme targeting $C$. odorata is needed as a cost effective management approach along with other control and restoration measures.

Keywords Biological invasions - Livelihoods · Local knowledge and perceptions - Negative impacts . Human well-being

\section{Introduction}

General introduction

Invasive species are an important driver of global change and have negative effects on humans and the environment (Pimentel et al. 2001; Pimentel 2002). They reduce biodiversity, de-couple the supply of ecosystem services and impact human wellbeing (Pejchar and Mooney 2009; van Wilgen et al. 2011; Simberloff et al. 2013). Research on invasions is crucial to guide management decisions to reduce costs of invasions and, in some cases, to improve benefits (Shackleton et al. 2015). However, most research on impacts of invasive species has been conducted from an ecological perspective; much less attention has been given to understanding the wider social dimensions of biological invasions, especially impacts on human livelihoods (see McNeely 2001; Shackleton et al. 2007; García-Llorente et al. 2008, 2011; Kull et al. 2011; 
Shackleton et al. 2015). Despite this, biological invasions are widely recognized to pose major and growing threats to human livelihoods in many parts of the world, especially in developing countries where the majority of people depend on natural resources (Shackleton et al. 2007; Kull et al. 2011; Simberloff et al. 2013). Studies assessing social perceptions and practices regarding invasive species provide insights into the understanding of the drivers and negative impacts of invasions, but also the attitudes, wants and needs of people regarding management interventions (Shackleton et al. 2007; García-Llorente et al. 2008; Mwangi and Swallow 2008; Kull et al. 2011; Rai et al. 2012). Such information is crucial for justifying management interventions, especially if the target species also have some benefits associated with them and as such could be regarded as "conflict species" (García-Llorente et al. 2008; van Wilgen and Richardson 2014; Shackleton et al. 2015; Novoa et al. 2016). Studies that assess social perceptions and the role of invasive species in people's lives are also important. We use Chromolaena odorata (L.) R.M. King \& H. Rob. (Asteraceae; Siam weed) as a case study to assess the effects of invasive plants on local livelihoods in northern-central Tanzania. Several studies have asserted that knowledge, perceptions, costs and benefits of invasive species change as invasions progress-as the invasive species occupies greater areas, and as the density of invasive populations increases (Shackleton et al. 2007; Kull et al. 2011; Shackleton et al. 2015). We use C. odorata to test this assertion.

\section{Chromolaena odorata}

Chromolaena odorata is a scrambling or climbing perennial shrub with distinctive three-veined, ovate to triangular leaves which grow opposite each other on brittle stems (Holm et al. 1977; Henderson 2001). When growing in isolation, shrubs usually attain heights of 2-3 m but they can attain heights of 5-10 m when supported by other vegetation. Two varieties or biotypes of $C$. odorata, both originating from the Americas, are widespread invasive shrubs (Rejmánek and Richardson 2013). One biotype is invasive in East and Southeast Asia, Australia, West and Central Africa (Zachariades et al. 2009), and invasive populations were recently discovered in Rwanda, Uganda, Tanzania and Kenya in East Africa (Zachariades et al. 2013). This biotype is also one of the most widespread invasive plants in western Angola (Rejmánek et al. 2016). This biotype has pale blue-lilac flowers and is fairly hairy while the other biotype which is invasive in southern Africa has hairless stems and leaves and has white flowers (Zachariades et al. 2009). Chromolaena odorata was introduced both intentionally and accidentally. For example, it was first introduced to India as an ornamental plant, and then accidentally into Southeast Asia through the movement of people and goods. In Australia and West Africa $C$. odorata was probably introduced accidentally as a contaminant of imported seed or fodder (Zachariades et al. 2009). It is now a widespread invasive shrub in many different habitats in most regions where it was introduced, impacting negatively on people and the environment and is both a driver and passenger of degradation. It threatens biodiversity by displacing native plant species, inducing allelopathy, altering soil properties, increases shading, reduces grazing potential for wildlife and livestock, and increases the intensity and frequency of fires in natural forested areas (Macdonald 1983; McFadyen 1989; Goodall and Morley 1995; McWilliam 2000; Mangla et al. 2008; Te Beest et al. 2015). It also has negative impacts on livelihoods, largely because of the loss of grazing and agricultural land (McWilliam 2000; Sakuntaladewi et al. 2016). However, a systematic investigation into this is still required to better assess knowledge and perceptions of local communities regarding the spread dynamics and impacts of $C$. odorata invasions. Such insights and better data on the distribution of this species are needed to guide management. This paper contributes to the understanding of the distribution of C. odorata in eastern Africa and its impacts on the livelihoods of local communities along a gradient of invasion density in Tanzania.

\section{Methods}

Study site

Mapping surveys for $C$. odorata were conducted in eastern Africa (Kenya, Rwanda, Tanzania and Uganda and Ethiopia) (Fig. 1). Additional information on the distribution of $C$. odorata was obtained from staff of the Grumeti Trust who undertook regular surveys in the Grumeti Reserve, Tanzania and adjoining protected and communal areas. 
Fig. 1 Maps showing the location of the surveyed countries in Africa (left) and the current distribution of $C$. odorata in eastern Africa (Ethiopia, Kenya, Rwanda, Tanzania and Uganda) (right). Black grid cells indicate surveyed areas where $C$. odorata was invasive (widespread or localized and abundant), dark grey cells where it was present and/or naturalized, and light grey cells show surveyed cells where the species was absent. Distribution is mapped at the resolution of half-degree grid cells $(\sim 55 \times 55 \mathrm{~km})$

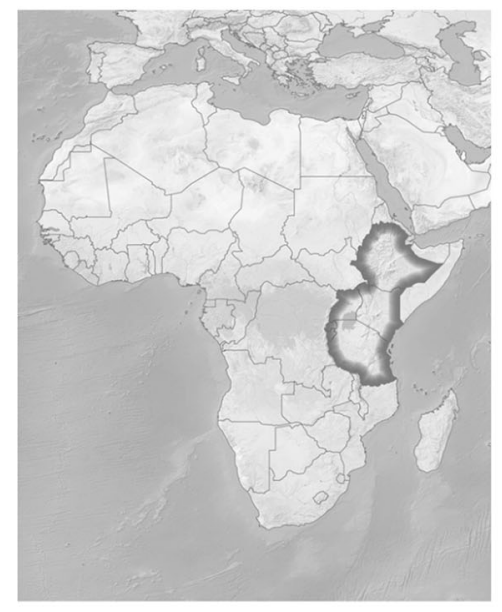

The livelihoods survey study was conducted in the northern-central part of Tanzania in the Mara Region, between Lake Victoria to the west and the Serengeti National Park in the east (Figs. 1, 2). Socio-economic surveys were conducted in four [Bunda, Musoma (Butiama), Serengeti and Tarime] of the seven districts of the Mara Region. These districts had varying degrees of invasion density of $C$. odorata, due to the fact that invasions first started in an area to the east of Lake Victoria, between the Mara River and the Kenyan border, in the north of Tanzania and are spreading southwards (see below). The Mara Region has bimodal rainfall. There is higher rainfall in the northern parts (Tarime) which receive $1250-2000 \mathrm{~mm} /$ year compared to the central zone (Musoma/Serengeti), which receives $900-1300 \mathrm{~mm} / \mathrm{year}$, and the lowland zone (Bunda) which receives 700-900 $\mathrm{mm} /$ year. The mean annual temperature in the region is $28.5^{\circ} \mathrm{C}$ (Regional Commissioners Office 2013). The Mara Region is relatively flat, with undulating hills. Soils vary from red sandy soils and sandy loams to grey and black calcareous clays. Grasslands dominate the landscape; these are interspersed with woodlands and occasional thickets, although large areas have been transformed by crop production, overgrazing and deforestation.

The villages consist primarily of the Wakulya, Wajaluo and Wajita clans, along with many other

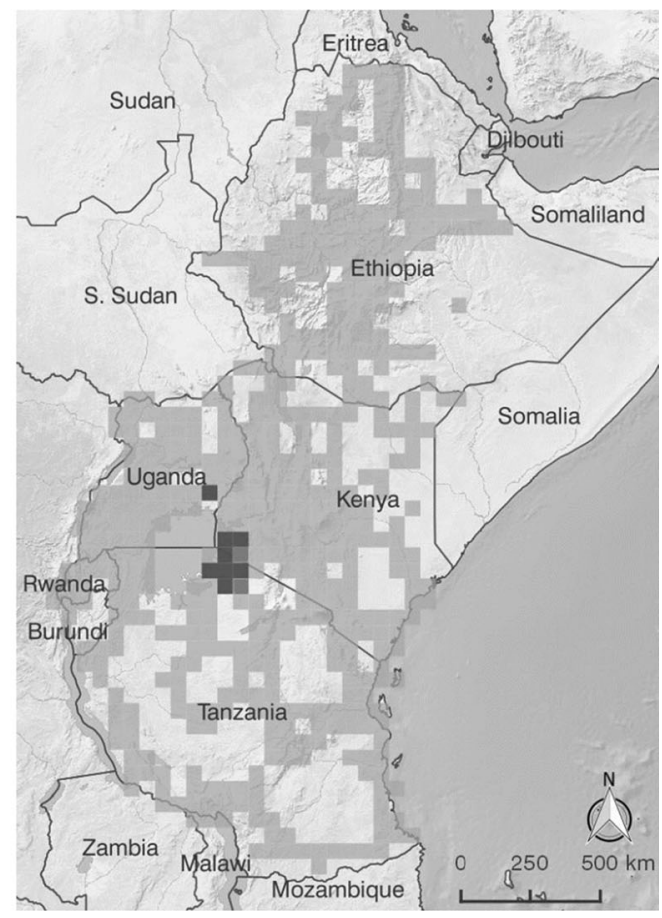

smaller clans. The dominant land use is subsistence rangeland grazing and cropping, with fishing being important around Lake Victoria (Regional Commissioners Office 2013). Approximately $90 \%$ of households depend on crop production for their livelihoods. The region has a population growth rate of $2.5 \%$, which is close to the national average $(2.7 \%)$. The Mara region has a population density of 80 people $/ \mathrm{km}^{2}$ which is higher than the Tanzanian average (49 people $/ \mathrm{km}^{2}$ ) (National Bureau of Statistics 2013). Very few people in the District are urbanized, and most are small-scale farmers (average of 3.2 ha./household). The area is poor and underdeveloped, and $36 \%$ of the population lives below the poverty line (Regional Commissioners Office 2013). The famous Serengeti National Park, an acclaimed World Heritage Site, falls within the Mara Region and is important for conservation, economic development and job creation in the area.

\section{Data collection}

\section{Mapping of Chromolaena odorata in East Africa}

Chromolaena odorata was mapped in the eastern African countries of Ethiopia, Kenya, Tanzania, Rwanda and Uganda (Fig. 1). Burundi and Somalia 


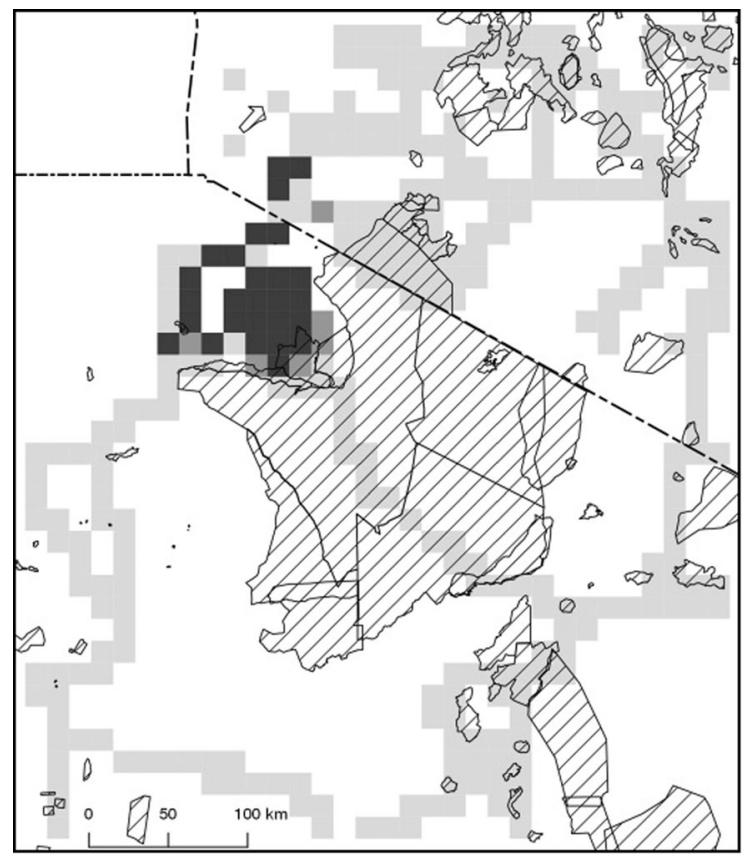

Fig. 2 Detailed map showing the distribution of $C$. odorata in northern-central Tanzania (Mara Region) where the socioeconomic survey was undertaken. Hatched areas are of the Serengeti-Mara ecosystem which includes the Serengeti national park in Tanzania, Maasai-Mara national reserve in Kenya and other protected areas. Grid cells where the species was not found are shaded light grey, while dark grey indicates presence and black denotes invasive populations. Grid cells are approximately $14 \times 14 \mathrm{~km}$ in size

were not surveyed due to political instability which prevented access. The presence and status of $C$. odorata was recorded using roadside surveys similar to those described by Henderson (2007) and Rejmánek et al. (2016). Such surveys are a cost-effective way of gaining a rapid and broad understanding of widespread distributions which can then guide more detailed mapping later. Coordinates, at or within $1 \mathrm{~km}$, of each locality where $C$. odorata was found to be present, naturalized or invasive (as defined by Pyšek et al. 2004) were recorded using a GPS. The distribution and abundance of $C$. odorata within eastern Africa was then mapped at the resolution of half-degree grid cells $(\sim 55 \times 55 \mathrm{~km})($ Fig. 1). Light grey grid cells indicate areas surveyed but where no $C$. odorata was seen, dark grey grid cells indicate areas where $C$. odorata was found to be present and/or naturalized, and black grid cells show areas where it was invasive (Fig. 1). It should be noted that in most cases only a part of each grid square could be surveyed, and as such the distribution maps are merely an approximation of the actual presence and density of $C$. odorata. Naturalized plants were considered to be those that had established small isolated self-perpetuating populations, but which were not yet invasive and spreading over large areas, and invasive populations were those which were widespread and abundant or localized, but nevertheless abundant, in the landscape (Pyšek et al. 2004). Additional information on the presence of $C$. odorata was obtained from surveys undertaken by staff from the Grumeti Fund. These were based on roadside and aerial surveys.

\section{Livelihoods survey}

Two hundred and forty households were interviewed in a random manner using semi-structured questionnaires in four districts of northern-central Tanzania with varying levels of $C$. odorata invasion (Fig. 2). This included Bunda and Serengeti (low density and localized invasions) with 47 and 82 respondents, respectively; Musoma with 48 (medium- to highdensity and localized invasive populations); and Tarime with 63 respondents (high-density and widespread invasions). The northern sites, which were grouped together because they had high-density invasions (widespread, abundant and dense with large monospecific stands common), were compared to the grouped southern sites, which were less invaded (isolated plants interspersed with small stands with a few monospecific stands in lowland areas). These groupings were based on the results of surveys which indicated that the northern areas had widespread and dense invasive populations compared to the south, where $C$. odorata was less abundant. The head of the household or next oldest member was interviewed in the local language (Kiswahili) with the help of a field assistant from the local Department of Environment and Agriculture. The questionnaires had four key sections and collected information on: (1) demographics of the respondent; (2) questions relating to his/her knowledge and perceptions about the introduction and spread of $C$. odorata; (3) questions relating to perceptions and knowledge on the negative impacts and benefits of $C$. odorata, with a particular focus on crop and pasture production; and (4) issues relating to the local practices, wants and needs pertaining to the management of $C$. odorata. 
Data analysis

Maximum likelihood Chi square $\left(\chi^{2}\right)$ analysis was used to assess differences between responses in areas with different invasion densities (low and high) for categorical data. Independent $t$ tests and MannWhitney $\mathrm{U}$ tests (when assumptions for the $t$ test were not met) were used to assess whether there were significant differences between responses of villages with different densities of $C$. odorata invasion (low and high) for numerical data. Values are reported in US\$ based on an exchange rate of $100 \mathrm{KSH}$ (Kenyan Shillings) to one US\$ (US Dollars).

\section{Results}

Distribution of Chromolaena odorata in eastern Africa

Chromolaena odorata was not found in Rwanda and Ethiopia despite extensive surveys of these countries (grey half-degree grid cells) (Fig. 1; Table 1). The species had previously been seen in the Akagera National Park, Rwanda (Zachariades et al. 2013; P. Goodman, pers. comm.), but was not seen there again during these surveys. These previously recorded invasive populations may have been "eradicated" in cropping areas outside of the National Park after it was significantly reduced in size after the Rwandan genocide.

Chromolaena odorata was found at a number of sites in and around Busitema Forest to the south of Tororo in eastern Uganda, and is probably more

Table 1 The percentage of grid squares (approximately $55 \times 55 \mathrm{~km}$ ) surveyed in each of the five eastern African countries together with the percentage of those grid squares in which $C$. odorata was found to be present/naturalized or invasive

\begin{tabular}{llll}
\hline Country & $\begin{array}{l}\text { \% grid } \\
\text { squares } \\
\text { surveyed }\end{array}$ & $\begin{array}{l}\text { \% grid squares } \\
\text { present or } \\
\text { naturalized }\end{array}$ & $\begin{array}{l}\% \text { grid } \\
\text { squares } \\
\text { invasive }\end{array}$ \\
\hline Ethiopia & 37 & - & - \\
Kenya & 65.2 & 0.7 & 1.5 \\
Rwanda & 83.3 & - & - \\
Tanzania & 49.1 & 0.6 & 2.9 \\
Uganda & 74.4 & - & 1.5 \\
\hline
\end{tabular}

widespread in this region than these surveys revealed. Despite intensive surveys along the western border between Uganda and the Democratic Republic of Congo (DRC), no invasive populations were found, although dense stands have been reported from eastern DRC (Q. Luke, pers. comm.).

Isolated, but nevertheless, dense populations were found in Migori County in the southwest of Kenya (Figs. 1, 2). Chromolaena odorata was also seen on the Siria escarpment on the edge of the Masai-Mara National Reserve. In northern Tanzania, the town of Tarime is considered to be the source of the $C$. odorata invasion in the region, and as such invasive stands here are very dense and widespread, often forming extensive monospecific stands, compared to the southern districts (Bunda and Serengeti), where the species is a more recent arrival, with isolated plants interspersed with small stands and occasionally larger stands which are confined to riparian zones or fallow croplands. The invasion is moving southwards and shows a density gradient from north (high) to south (lower). Invasions are also moving to the east, threatening the iconic Serengeti National Park.

Demographic data

Demographic information provided by respondents was comparable to the official provincial demographic information and did not differ considerably between areas with high- and low-density $C$. odorata invasions (Table 2). About a third of respondents in the study area were male, and all respondents in both sites considered themselves to be farmers. Most respondents owned livestock (96\% in areas with low- and $97 \%$ in areas with high-density invasions) and cultivated crops (89\% in low- and 94\% in high-density invaded areas) (Table 2). The mean age ( \pm SD) of respondents was $46 \pm 11$ and most (88\%) had only primary school education. Household size was slightly higher in the areas with low-density invasions $(9 \pm 5)$ compared to those in sites with dense invasions $(7 \pm 5)$.

Most households (88\%) that owned livestock grazed their animals between 1 and $5 \mathrm{~km}$ from where they resided. The average number of cattle (21) per household was not significantly different between the different sites (Table 2). However, the mean number of goats and sheep owned did differ significantly; households living in areas with low-density $C$. odorata 
Table 2 The respondent and household (hh) demographics of the sampled populations in areas with different densities (high and low) of C. odorata (mean $\pm \mathrm{SD}$ )

\begin{tabular}{llll}
\hline & High densities & Low densities & Statistics \\
\hline \% Male & 66 & 58 & $\chi^{2}=3.599 ; p=0.58$ \\
Age (years) & $45 \pm 12$ & $46 \pm 11$ & $\mathrm{t}=-0.329 ; p=0.74$ \\
Household size & $7 \pm 5$ & $9 \pm 5$ & $\mathrm{t}=2.410 ; p=0.017$ \\
Education (years) & $7 \pm 2$ & $8 \pm 2$ & $p=0.064$ \\
Occupation (\% farmer) & 100 & 100 & $\chi^{2}=1.24 ; p=0.35$ \\
$\%$ of hh with livestock & 97 & 96 & $\chi^{2}=0.89 ; p=0.31$ \\
Mean no. of goats and sheep per hh & $11 \pm 13$ & $26 \pm 33$ & $\mathrm{t}=4.803 ; p<0.0001$ \\
Mean no. of cattle per hh & $20 \pm 23$ & $23 \pm 37$ & $\mathrm{t}=1.637 ; p=0.103$ \\
$\%$ with fields (grow crops) & 93 & 86 & $\chi^{2}=240.0 ; p<0.0001$ \\
Field size (ha) & 1.7 & 1.8 & $\chi^{2}=1.89 ; p=0.086$ \\
\hline
\end{tabular}

invasions had more sheep and goats $(26 \pm 33)$ than those residing in densely invaded areas $(11 \pm 13)$. Significantly more respondent households in the highly invaded areas (93\%) grew crops than those in areas which were less invaded $(86 \%)$, possibly because the north receives higher rainfall. Maize, sorghum and cassava (in order of importance) were the main crops cultivated, while some also grew cotton and finger millet; very few grew bananas, tobacco and sunflowers. The majority of respondents $(63 \%)$ had fields between 1.5 and 2 ha. in extent and there was no significant difference in field sizes between areas with different densities of $C$. odorata.

Local knowledge and perceptions

of the introduction and spread of $C$. odorata

About two-thirds of villagers had a good idea of when C. odorata first established in their area; the rest were unsure (Fig. 3). Twice as many respondents living in areas with high-density invasions knew when $C$.

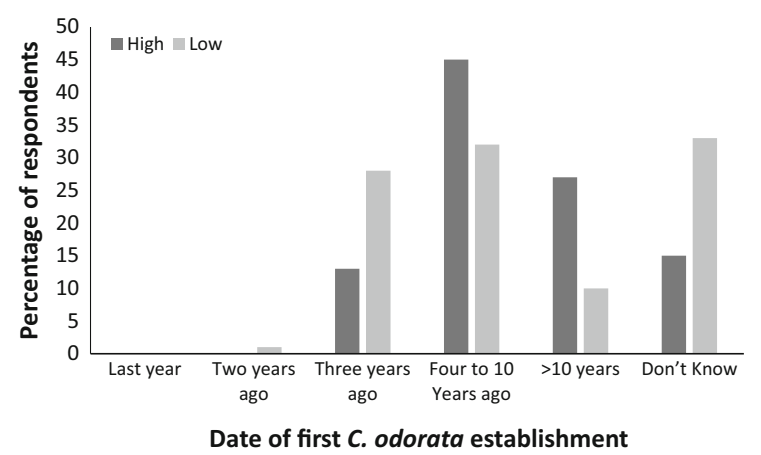

Fig. 3 Perceptions of villagers regarding the date of arrival of Chromolaena odorata at sites with high- and low-density invasion levels $\left(\chi^{2}=24.81 ; p=0.000\right)$ odorata arrived in their area, compared to those living in areas with low-density invasions. More villagers in the areas with low-density invasions (28\%) stated that C. odorata had arrived in the last three years, compared to $13 \%$ in areas with dense invasions. About 32 and $45 \%$ of respondents in areas with low and high-density invasions, respectively, stated that $C$. odorata had established in their area between 4 and 10 years ago, whereas fewer (10\% in low- and $27 \%$ in areas with dense invasions) believed that $C$. odorata had established around their villages more than 10 years ago (Fig. 3).

Most respondents in areas with high- and lowdensity invasions were unsure how or why $C$. odorata was introduced to their area, but had a better understanding of the vectors of spread (Table 3 ). In both areas, very few $(<10 \%)$ villagers believed it to have been introduced as a garden plant or for green manure, and fewer mentioned that it was introduced for hedging. Most respondents (81\%) living in areas with high-density invasions thought that $C$. odorata spreads naturally, which is a significantly higher proportion of respondents than in areas with low-density invasions $(32 \%)$. Conversely, significantly more respondents $(22 \%)$ in areas with low-density invasion levels held the view that livestock were the main vector of spread, compared to only $4 \%$ of respondents living in areas with dense invasions. More than three-quarters of all respondents stated that $C$. odorata is spreading and increasing in density in their area.

\section{Socio-ecological stressors}

Numerous socio-ecological stressors were considered to be a threat to the livelihoods of the communities in 
Table 3 Perceptions of villagers regarding the pathways of introduction and vectors of spread for $C$. odorata in areas with highand low-density invasions

\begin{tabular}{llll}
\hline & $\begin{array}{l}\text { High- density } \\
\text { stands }\end{array}$ & $\begin{array}{l}\text { Low-density } \\
\text { stands }\end{array}$ & $p$ value \\
\hline Reasons for introduction & & & \\
$\quad$ Hedge plant & 3 & 5 & $\chi^{2}=0.117 ; p=0.773$ \\
Garden plant & 7 & 7 & $\begin{array}{l}\chi^{2}=0.194 ; p=0.344 \\
\chi^{2}=0.369 ; p=0.544\end{array}$ \\
Green manure & 8 & 3 & $\chi^{2}=2.62 ; p=0.106$ \\
Don't know & 76 & 74 & $\chi^{2}=11.205 ; p=0.001$ \\
Vectors of spread & 4 & 22 & $\chi^{2}=32.008 ; p<0.0001$ \\
$\quad$ Livestock & 81 & 32 & $\chi^{2}=10.275 ; p=0.001$ \\
$\quad$ Natural (wind and water) & 19 & 48 & $\chi^{2}=1.509 ; p=0.219$ \\
$\quad$ Don't know & & 84 & \\
Spreading & 87 & & \\
Spreading (\% responding yes) & & & \\
\hline
\end{tabular}

Table 4 Percentage of respondents mentioning different socio-ecological stressors for local livelihoods in areas with high- and low-density $C$. odorata invasions

\begin{tabular}{llll}
\hline & $\begin{array}{l}\text { High } \\
\text { densities }\end{array}$ & $\begin{array}{l}\text { Low } \\
\text { densities }\end{array}$ & $p$ value \\
\hline $\begin{array}{l}\text { Insufficient } \\
\text { grazing }\end{array}$ & 32 & 32 & $\chi^{2}=0.06 ; p=0.783$ \\
$\begin{array}{l}\text { Weeds } \\
\begin{array}{l}\text { Insufficient } \\
\text { water }\end{array}\end{array}$ & 15 & 15 & $\chi^{2}=0.064 ; p=0.755$ \\
$\begin{array}{l}\text { Disease } \\
\text { isear }\end{array}$ & 22 & 20 & $\chi^{2}=0.072 ; p=0.697$ \\
\hline
\end{tabular}

northern-central Tanzania (Table 4). Invasive species were ranked as important, along with insufficient grazing and water and the prevalence of livestock diseases. Invasive species, including $C$. odorata, probably compound the stressors relating to insufficient grazing and water. In the study area, $C$. odorata was ranked as the worst plant invader in both rangeand croplands (Table 5; Box 1). Other weeds with impacts in both range- and croplands were Lantana camara L. (Verbenaceae), and to a lesser extent Opuntia stricta (Haw.) Haw. (Cactaceae), and Argemone species (Papaveraceae). Datura stramonium L. (Solanaceae) was also seen as being problematic in rangelands, but less so than $C$. odorata. The hemiparasitic plant Striga hermonthica (Delile) Benth. (Orobanchaceae) was rated as having negative impacts in croplands, but was also considered less of a problem than $C$. odorata.

\section{Impacts of Chromolaena odorata}

Most respondents highlighted that $C$. odorata causes significant negative impacts. A few respondents stated that it provided benefits. Negative impacts were reported significantly more by villagers living in areas

Table 5 Percentage of respondents ranking different invasive plant species that have negative impacts in range- and cropland in areas with high- and low-density $C$. odorata invasions

\begin{tabular}{|c|c|c|c|c|c|c|}
\hline \multirow[t]{2}{*}{ Species } & \multicolumn{3}{|c|}{ Rangelands } & \multicolumn{3}{|c|}{ Croplands } \\
\hline & $\begin{array}{l}\text { High } \\
\text { density }\end{array}$ & $\begin{array}{l}\text { Low } \\
\text { density }\end{array}$ & Stats & $\begin{array}{l}\text { High } \\
\text { density }\end{array}$ & $\begin{array}{l}\text { Low } \\
\text { density }\end{array}$ & Stats \\
\hline Chromolaena odorata & 31 & 33 & $\chi^{2}=3.097 ; p=0.41$ & 29 & 35 & $\chi^{2}=5.097 ; p=0.221$ \\
\hline Lantana camara & 18 & 15 & $\chi^{2}=2.866 ; p=0.452$ & 11 & 7 & $\chi^{2}=4.016 ; p=0.152$ \\
\hline Argemone spp. & 5 & 6 & $\chi^{2}=0.819 ; p=0.761$ & 5 & 6 & $\chi^{2}=0.819 ; p=0.761$ \\
\hline Datura stramonium & 11 & 11 & $\chi^{2}=0.683 ; p=0.561$ & - & - & - \\
\hline Opuntia stricta & 18 & 10 & $\chi^{2}=8.131 ; p=0.005$ & 1 & 5 & $\chi^{2}=7.486 ; p=0.036$ \\
\hline Striga hermonthica & - & - & - & 24 & 13 & $\chi^{2}=8.227 ; p=0.005$ \\
\hline
\end{tabular}


Box 1 Quotes from pastoralists highlighting local knowledge and perceptions of $C$. odorata invasions in East Africa

1. "Chromolaena has killed us because it has killed our crops and our livestock." Group discussion with village elders, Serengeti, Tanzania

2. "Anyone who would help us to eradicate these weeds shall be our God on earth." Elizabeth John Stephen, Kwigutu, Tanzania

3. "Agriculture becomes very difficult because of this dangerous plant." John Wambura Gimanje, RWA, Tanzania

4. "I lack a place to graze my livestock. My livestock grow thinner and even die of starvation. Government help us folks"

Monica Robert, Nyasirori, Tanzania

5. "Cows produce very little milk these days and weigh as much as a goat." Chichi Marwa, Kyankoma, Tanzania

Table 6 Respondents' $(\%)$ perceptions on the benefits and costs of $C$. odorata in areas with high- and low-density invasions (mean no. of respondents)

\begin{tabular}{llll}
\hline Costs and benefits & High density & Low density & $p$ value \\
\hline Costs & & & \\
Decrease grass & 82 & 54 & $\chi^{2}=19.943 ; p<0.0001$ \\
Decrease shrubs & 80 & 51 & $\chi^{2}=20.181 ; p<0.0001$ \\
Decrease trees & 66 & 56 & $\chi^{2}=2.072 ; p=0.150$ \\
Decrease wildlife & 25 & 21 & $\chi^{2}=0.501 ; p=0.479$ \\
Decrease water & 67 & 54 & $\chi^{2}=4.051 ; p=0.046$ \\
Decrease movement & 94 & 84 & $\chi^{2}=702 ; p=0.03$ \\
Decrease availability of useful plants & 39 & 31 & $\chi^{2}=7.839 ; p=0.02$ \\
Negative effects of livestock health & 80 & 63 & $\chi^{2}=7.810 ; p=0.005$ \\
Impact livestock (no. lost) & $10 \pm 12$ & $5 \pm 9$ & $p=0.002$ \\
Decrease crop yields & 90 & 74 & $\chi^{2}=9.074 ; p=0.003$ \\
Benefits & & & \\
Hedge plant & 14 & 14 & $\chi^{2}=0.004 ; p=0.949$ \\
Medicinal plant & 17 & 19 & $\chi^{2}=0.312 ; p=0.577$ \\
No benefits & 75 & 77 & $\chi^{2}=0.336 ; p=0.562$ \\
\hline
\end{tabular}

with high-density invasions compared to those living in areas with less dense invasions (Table 6). A greater number of respondents (66-82\%) in areas with dense invasions stated that $C$. odorata reduces the presence of native grasses, shrubs and trees than those living in areas where the species was less abundant (51-56\%) (Table 6). Negative impacts on wildlife were reported to be less of a problem in both areas compared to impacts on plants (Table 6).

Negative impacts on water availability were reported as more of a problem by respondents living in areas with dense $C$. odorata invasions than those with less dense stands (Table 6). Impaired access and movement due to invasions was ranked as one of the major issues in both areas, but was still stated significantly more $(94 \%)$ by locals in areas with high-density invasions compared to areas with less dense invasions $(84 \%)$. The loss of beneficial plants (e.g. for medicinal use) was mentioned on average by $35 \%$ of respondents at both sites. Locals perceive that C. odorata has significantly greater impacts on livestock in areas where it is widespread and abundant (80\%) than in areas with less dense invasive stands $(63 \%)$. These impacts included negative effects on milk quality, livestock weight and health, and $C$. odorata is even blamed for causing death of livestock by some respondents (Box 1). In areas where $C$. odorata is abundant, respondents reported the loss (on average) of 10 livestock/year as opposed to 5 livestock/year in areas with less dense invasions. Loss of crop yields due to $C$. odorata was ranked as a problem by the majority of respondents in both areas (90\% in high-density invasions areas versus $74 \%$ in areas with less dense invasions). Chromolaena odorata has resulted in a substantial loss of grazing land and causes crop losses of over 50\% (Fig. 4; Box 1). 
Three quarters of respondents in both sites felt that C. odorata yielded no benefits (Table 6). However, some identified that it was used for hedging and as a medicinal plant by 17 and $19 \%$ of respondents in areas with low and high levels of $C$. odorata, respectively (Table 6).

\section{Management of Chromolaena odorata}

Most respondents in both sites (87\% in high-density and $73 \%$ in low-density invasions) stated that $C$. odorata is present on their rangelands. Furthermore, more than three quarters of respondents view $C$. odorata invasions to be increasing in both areas. Three quarters of respondents in areas with dense invasions and half of the respondents in areas with less dense stands reported managing $C$. odorata in rangelands. Control mainly involved the slashing of plants at ground level, with no real attempt to remove the rootstock, with the result that the plants readily coppiced and required repeated control. A quarter of
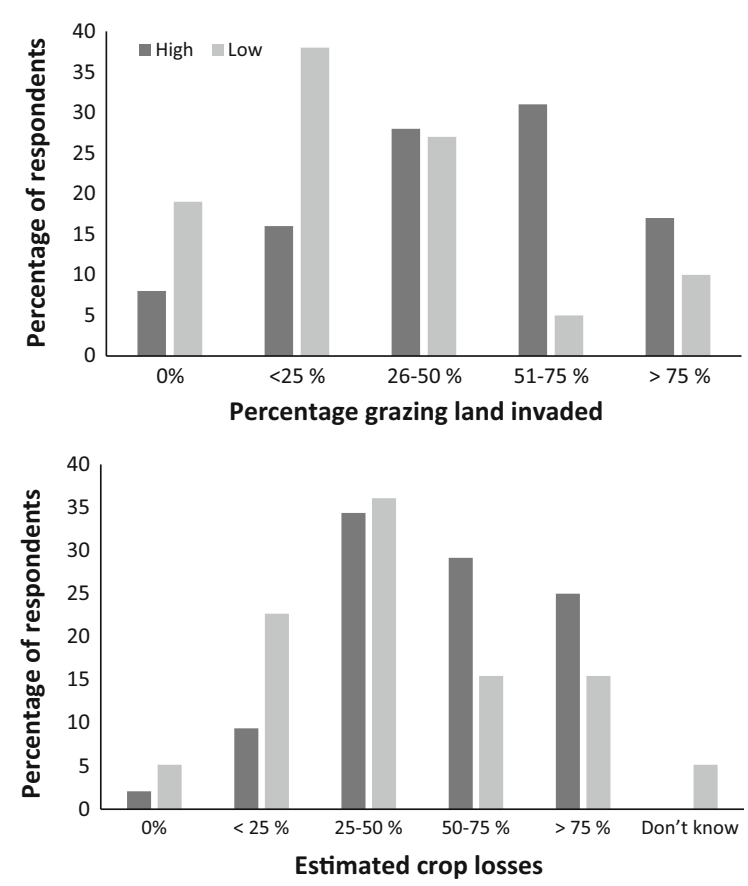

Fig. 4 Respondent's estimation of grazing land invaded by $C$. odorata in areas with high- and low-density invasions $\left(\chi^{2}=34.016 ; \quad p=0.003\right) \quad($ top $) ; \quad$ Estimated crop loss attributable to $C$. odorata ranked by households living in areas with high- and low-density invasions $\left(\chi^{2}=17.799 ; p=0.003\right)$ (bottom) respondents (23\%) occasionally used fire to control $C$. odorata.

Management of $C$. odorata within croplands is more systematic, with people clearing it every few months in areas with high-density stands, compared to 2-3 times/year in areas with sparser stands. This mainly involved slashing and hoeing to remove root stocks. In areas where $C$. odorata is abundant, more households (42\%) pay for labour to clear fields, compared to those in areas with less dense stands $(21 \%)$. Wages for people clearing land are higher in areas with dense invasions, with an average of US\$ 550 compared to US\$ 340 per annum.

Most respondents $(81-100 \%)$ in both sites felt strongly that the decreased presence of $C$. odorata would benefit human well-being and that management is needed (Box 1). Many respondents suggested that external help would be appreciated to aid them in managing C. odorata (Box 1).

\section{Discussion}

Distribution and impacts of C. odorata

Chromolaena odorata has a fairly localized distribution in eastern Africa. It is only prevalent in northerncentral Tanzania, and south-eastern Kenya, with some invasive populations in eastern Uganda. There are no formal records as to when it was first recorded in Tanzania although some experts are of the opinion that it has been present for at least $10-15$ years. This is supported by the response from villagers, most of who stated that it was first seen 4-10 years ago. Despite its current limited distribution, bioclimatic models in other studies have indicated that much of the region is climatically suitable for the species, especially areas along the Kenyan and Tanzanian coasts, large parts of Uganda and areas around Lake Victoria (McFadyen and Skarratt 1996; Kriticos et al. 2005; Raimundo et al. 2007). This is in agreement with more than threequarters of respondents who suggest that $C$. odorata is continuing to spread and increase in density. This highlights that invasion of this species in the region is at a fairly early stage and that further spread and densification can be expected which will increase negative impacts. The broad-scale surveys undertaken in this study have been useful to show where more intensive surveys are required. 
The view that $C$. odorata invasions have significant negative impacts on the environment and local livelihoods is shared by most villagers who ranked it as the worst weed in the area and a serious socio-ecological stressor. Villagers interviewed highlighted numerous impacts of $C$. odorata on biodiversity, livestock and crop production, water and valuable plant species. Our results agree with those from previous studies (McWilliam 2000; Sakuntaladewi et al. 2016) that suggest that C. odorata negatively affects livelihoods mainly through encroachment of grazing and agricultural lands. Reductions in crop yields due to invasion in fields have also been highlighted by communities for C. odorata in Indonesia (Sakuntaladewi et al. 2016), and for other invasive species such as Mikania micrantha Kunth (Asteraceae) in Papua New Guinea (Day et al. 2012), Lantana camara in South Africa (Jevon and Shackleton 2015), and Parthenium hysterophorus L. (Asteraceae) in Ethiopia (Tamado and Milberg 2000). In Indonesia, C. odorata reduces yields of oil palm, rubber, coffee, forestry species, fruit orchards, rice paddies and tobacco, and has been noted to be a key driving factor behind field abandonment (Waterhouse 1993; CRC for Weed Management 2003; Sakuntaladewi et al. 2016). In the USA, invasive plant species are estimated to reduce crop yields by $12 \%$ which is an equivalent loss of over US\$20 billion annually (Pimentel et al. 2001). Respondents considered $C$. odorata to reduce native plant abundance and diversity, and impact negatively on wildlife. Through various mechanisms (allelopathy, shading, water use, and increased fire frequency and intensity), C. odorata has been seen to reduce the presence of native plants, especially valuable forage species, in rangelands and conservation areas (Macdonald 1983; McFadyen 1989; Goodall and Morley 1995; McWilliam 2000; Mangla et al. 2008). Dense stands of $C$. odorata also impede movement (access) for humans and livestock, a problem caused by many invasive plant species as they encroach on land (Chikuni et al. 2004; Sundaram et al. 2012; Aloo et al. 2013). The impact of invasive plant species on water resources has been recorded elsewhere (Woodall 1981; Le Maitre et al. 2004; Dzikiti et al. 2013) and is suggested to be the same for $C$. odorata. Meijninger and Jarmain (2014) highlight that the evapotranspiration, and therefore water uptake/loss attributable to $C$. odorata (ET 1020) is much higher than that of native forests (ET 680) and savannas (ET $685)$ in South Africa. Our results also show that local knowledge, perceptions and practices regarding invasive species and livelihood impacts are different in areas with differing levels of invasion density, as suggested by Shackleton et al (2007) framework. Thus, as invasions increase, impacts on human vulnerability proliferate, with increasingly negative impacts on human well-being.

Although this study focussed on the direct impacts of C. odorata on human livelihoods, there is substantial evidence that the species also has negative effects on biodiversity, which could have knock-on impacts on other economic sectors such as tourism. For example, invasions of $C$. odorata have been noted to reduce small mammal species richness and diversity and community structure and diversity for large mammals in Hluhluwe-iMfolozi Game Reserve in South Africa (Dumalisile 2008). In the same area, Goodall and Morley (1995) found that dense stands of $C$. odorata reduce carrying capacities from 6 ha./large stock unit to 15 ha./large game unit. This is because $C$. odorata is unpalatable and displaces native forage species, thereby reducing grazing potential. Chromolaena odorata is also likely to invade the Serengeti-Mara ecosystem which will have devastating impacts on wildlife, including the annual wildebeest migration, one of the natural wonders of the world (A.B.R. Witt et al. unpubl.). An associated reduction in tourism as a result of invasions will also have an indirect impact on community members who are employed in this sector.

With reference to the framework linking invasive species and livelihoods proposed by Shackleton et al. (2007), C. odorata can be categorised as an undesirable and strongly competitive weed that brings few benefits and incurs high costs. Our results are in accordance with this framework which demonstrates that as abundance increases, costs or negative impacts increase, which leads to greater vulnerability to human livelihoods. These results indicate that further spread is likely to induce further costs and threats to human well-being with concomitant negative impacts on the environment. Urgent management interventions are clearly justified.

Management of $C$. odorata to reduce spread and negative impacts

Chromolaena odorata is a fairly recent invader in eastern Africa but has the potential to spread over large parts of the region (McFadyen and Skarratt 1996; Kriticos et al. 2005; Raimundo et al. 2007). Careful 
monitoring is required and $C$. odorata needs to be eradicated from areas where it has recently established and contained in areas where it is already well established. Various management options and approaches exist for managing invasive plants. These include physical, chemical, biological, and in in some cases also cultural control methods such as fire and flooding, as well as prioritising areas for eradication, containment and asset protection (Grice et al. 2011; van Wilgen et al. 2011). For example, fire has been used in managing $C$. odorata invasions in parts of South Africa but with mixed success (Goodall and Zachariades 2002; Witkowski 2002; te Beest et al. 2012). A single treatment fire does not control $C$. odorata as large shrubs are fire-tolerant and can resprout, even after high-intensity fires (te Beest et al. 2012). In any case, overgrazing in much of the Mara Region means that there is insufficient fuel to carry the high-intensity fires that would be required to make such a management intervention effective. Manual control, followed by fire, can be effective but the accumulation of large amounts of dead biomass results in intense fires that have a negative impact on the native vegetation (te Beest et al. 2012). It is also unlikely that manual control will be practiced at a large scale in communal rangelands anyway, and applying fire without combined mechanical clearing is unlikely to be useful. Also, fires can facilitate invasions by other species (Eussen and de Groot 1974; Gautier 1996; Wilson and Mudita 2000). Although interventions, such as chemical and manual control can be cost-effective in croplands such methods are generally not used in rangelands, especially in eastern Africa, where grazing land is utilized communally. The above-mentioned factors suggest that biological control holds the key to reducing the escalating problem of $C$. odorata invasions in eastern Africa.

Biological control of $C$. odorata has been successfully implemented in some areas starting in the 1960s, and numerous agents have been released in the Pacific, southern and western Africa and South East Asia (Zachariades et al. 2009). Agents include the moth Pareuchaetes pseudoinsulata Rego Barros (Erebidae). This species has been widely introduced and has shown success in controlling $C$. odorata in some areas (parts of Asia Pacific, Ghana and Nigeria), although it failed to establish in other areas (several African countries, Vietnam and Thailand) (Waterhouse 1994; Desmier de Chenon et al. 2002; Zachariades et al.
2009, Uyi and Igbinosa 2013). Another species, Pareuchaetes insulata (Walker) (Erebidae), has established and shows good control of the C. odorata biotype found in South Africa, especially in the wetter areas of the country (Zachariades and Strathie 2006). Cecidochares connexa (Macquart) (Tephritidae), a stem-galling fly, has established and has been successful in controlling $C$. odorata in parts of South East Asia and has recently established in Cote d'Ivoire and Ghana (Desmier de Chenon et al. 2002; Day and Bofeng 2007; Zachariades et al. 2009; Uyi and Igbinosa 2013; Day et al. 2013; A.B.R. Witt, pers. obs.). Cecidochares connexa has also recently been released in northern-central Tanzania. Monitoring is needed to confirm that is has established permanently and to assess its effectiveness in controlling $C$. odorata. If $C$. connexa establishes, it should provide substantial control which could be enhanced with the introduction of other host-specific and damaging agents (Zachariades et al. 2009).

The introduction of biological control in Sumatra (Indonesia) has reduced maintenance costs for $C$. odorata in plantations by $75 \%$ (Desmier de Chenon et al. 2002). For local communities in the Musu and Sendaun Provinces, biocontrol of $C$. odorata has led to increased numbers of food gardens, and has reduced weeding time and costs by over $75 \%$, doubling incomes of local households. Similar reports have been noted in other communities in Sumatra (Zachariades et al. 2009). In Papua New Guinea, 60-80\% of 190 land owners in different villages reported that the biocontrol agent $C$. connexa had reduced the density of $C$. odorata invasions, with $50 \%$ of respondents reporting a $50 \%$ reduction in invasion densities (Day et al. 2013). They also reported that weeding time for C. odorata had halved due to the biological control agent and $60 \%$ of respondents reported increased yields and incomes (Day et al. 2013). In Ghana, biological control has reduced the abundance of $C$. odorata and improved the growth of important fodder plants [Pennisetum purpureum Schumach. (Poaceae) and Aspilia africana (Pers.) C.D. Adams (Asteraceae)], improving grass cover from $2 \%$ to over $24 \%$ (Timbilla et al. 2003). In South Africa, it is estimated that the cost of biological control of $C$. odorata is $10 \%$ of that of manual clearing and is effective at sustaining low levels of invasion (Zachariades et al. 2009).

Many countries in Africa are reluctant to introduce agents for the control of invasive plants despite the fact 
that biological control been practiced for well over 100 years with intentional releases having been made in 90 countries (Winston et al. 2014). By the end of 2012, there were 1555 separate and intentional releases of 469 species of weed biological control agents against 175 species of non-native target weeds (when related taxa of unidentified plant species, such as some Opuntia species, are counted as single target weeds) (Winston et al. 2014). For example, $C$. connexa has been tested in eight countries and on over 130 plant species over a number of years. It has been deemed safe and has been released in 10 countries (Day et al. 2016). Effective biological control could help prevent further spread, reduce negative impacts and improve local well-being.

If management interventions are not implemented a reduction in available forage, especially in communal lands, is likely to put increasing pressure on protected area managers to make conservation land available for livestock production. This situation may result in an increase in human-wildlife conflicts, especially in cases where livestock are lost to predators. An increase in the extent and density of invasive stands is likely to increase poverty levels, which may lead to a concomitant increase in poaching, as communities struggle to survive. Invasions may also drive conflict within and between communities as they compete for access to natural resources such as grazing and water. It is imperative that a $C$. odorata management plan be developed and implemented along with improved rangeland management through better agricultural extension and education to prevent reinvasion. Building awareness to promote and encourage buy-in for $C$. odorata control and to raise external funding is also crucial.

Acknowledgements RTS, DMR and AW acknowledge support from the DST-NRF Centre of Excellence for Invasion Biology (C.I.B). During the writing of the paper AW was supported as a C.I.B Fellow. RTS acknowledges additional support from Stellenbosch University through "Consolidoc" funding through the office of the Vice Rector: Research, Innovation and Postgraduate Studies. DMR received support from the National Research Foundation of South Africa (Grant 85417). CABI through the CABI Development Fund funded much of this work, including the socio-economic surveys, while the JRS Biodiversity Foundation provided resources to undertake surveys and produce distribution maps. Tim Beale (CABI) developed the maps. Thanks to Mr Victor Rotonesha and staff from the local Department of Environment and Agriculture for assisting with the socio-economic surveys and the Grumeti Fund and staff for supporting much of the work.

\section{References}

Aloo P, Ojwang W, Omondi R, Njiru MN, Oyugi D (2013) A review of the impacts of invasive aquatic weeds on the biodiversity of some tropical bodies with special reference to Lake Victoria (Kenya). Biodivers J 4:471-482

Chikuni MF, Dudley CO, Sambo EY (2004) Prosopis glandulosa Torrey (Leguminosae-Mimosoidae) at Swang'oma, Lake Chiwa plain: a blessing in disguise? Malawi J Sci Technol 7:10-16

CRC for Weed Management (2003) Weed management guide: Siam weed or chromolaena (Chromolaena odorata). CRC for Australian Weed Management, Commonwealth Department of Environment and Heritage

Day M, Bofeng I (2007) The status of biocontrol of Chromolaena odorata in Papua New Guinea. In: Lai PY, Reddy GVP, Muniappan RT (eds) Proceedings of the seventh international workshop on biological control and management of Chromolaena and Mikania. National Pingtung University, Taiwan, pp 53-67

Day MD, Kawi A, Kurika K, Dewhurst CF, Waisale S, Saul-Maora J, Fidelis J, Bokosou J, Moxon J, Orapa W, Senaratne KADW (2012) Mikania micrantha Kunth (asteraceae) (mile-a-minute): its distribution and physical and socioeconomic impacts in Papua New Guinea. Pac Sci 66:213-223

Day MD, Bofeng I, Nabo I (2013) Successful biological control of Chromolaena odorata (Asteraceae) by the gall fly $\mathrm{Ce}$ cidochares connexa (Diptera: Tephritidae) in Papua New Guinea. In: Wu Y, Johnson T, Sing S, Raghu S, Wheeler G, Pratt P, Warner K, Center T, Goolsby J, Reardon R (eds) Proceedings of the XIII International Symposium on Biological Control of Weeds, Waikoloa (Hawaii USA), September 2011. Forest Health Technology Enterprise Team, Morgantown WV, pp 400-408

Day MD, Riding N, Senaratne KADW (2016) The host specificity and climatic suitability of the gall fly Cecidochares connexa (Diptera: tephritidae), a potential biological control agent for Chromolaena odorata (Asteraceae) in Australia. Biocontrol Sci Tech 26:691-706

Desmier de Chenon R, Sipayung A, Sudharto P (2002) A decade of biological control against Chromolaena odorata at the Indonesian Oil Palm Research Institute in Marihat. In: Proceedings of the 5th international workshop on biological control and management of Chromolaena odorata. Zachariades C, Muniappan R, Strathie LW (eds) ARCPPRI, Pretoria, South Africa, pp 46-52

Dumalisile L (2008) Effects of Chromolaena odorata on mammalian biodiversity in Hluhluwe-iMfolozi Park, South Africa. University of Pretoria, Pretoria, South Africa, Masters in Science (Wildlife Management)

Dzikiti S, Schachtschneider K, Naiken V, Gish M, Moses G, Le Maitre DC (2013) Water relations and the effects of clearing invasive Prosopis trees on groundwater in an arid environment in the Northern Cape, South Africa. J Arid Environ 90:103-113

Eussen JHH, de Groot W (1974) Control of imperata cylindrical (L.) Beauv. in Indonesia. Mededelingen Fakulteit Landbouw-wetenschappen Gent 39:451-464

García-Llorente M, Martín-López B, González JA, Alcorlo P, Montes C (2008) Social perceptions of the impacts and 
benefits of invasive alien species: implications for management. Biol Conserv 141:2969-2983

García-Llorente M, Martín-Lopes B, Nunes PA, González JA, Alcorlo P, Montes C (2011) Analyzing the social factors that influence willingness to pay for invasive species management under two different strategies: eradication and prevention. Environ Manag 48:418-435

Gautier L (1996) Establishment of Chromolaena odorata in a savanna protected from fire: an example of the Lamto central Côte d'Ivoire. In: Proceedings from the third international chromolaena workshop, University of guam, publication no. 202, Abidjan, pp 54-67, November 1993

Goodall JM, Morley TA (1995) Ntambanana vegetation survey and veld improvement plan. Unpublished report submitted to the Mpendle Ntambanana Agricultural Company

Goodall JM, Zacharias PJK (2002). Managing Chromoleana odorata in subtropical grasslands in KwaZulu-Natal, South Africa. In Zachariades C, Muniappan R, Strathie LW. Proceedings of the Fifth International Workshop on Biological Control and Management of Chromolaena odorata, Durban South Africa, 23-25 October 2000. ARC-PPRI pp 120-127

Grice AC, Clackson JR, Calver M (2011) Geographic differentiation of management objectives for invasive species: a case study of Hymenachne amplexicaulis in Australia. Environ Sci Policy 14:986-997

Henderson L (2001) Alien weeds and invasive plants. Plant protection research institute handbook no. 12. Paarl Printers, Cape Town, 298 pp

Henderson L (2007) Invasive, naturalised and casual alien plants in southern Africa: a summary based on the South African plant invaders atlas (SAPIA). Bothalia 37:215-248

Holm L, Doll J, Holm E, Pancho J, Herberger J (1977) World weeds: natural histories and distribution. Wiley, New York, $1129 \mathrm{pp}$

Jevon T, Shackleton CM (2015) Integrating local knowledge and forest surveys to assess Lantana camara impacts on indigenous species recruitment in Mazeppa Bay, South Africa. Hum Ecol 43:247-254

Kriticos DJ, Yonow T, McFadyen RE (2005) The potential distribution of Chromolaena odorata (Siam weed) in relation to climate. Weed Res 45:246-254

Kull CA, Shackleton CM, Cunningham PJ, Ducatillon C, Dufour-Dror J, Esler KJ, Friday JB, Gouveia AC, Griffin AR, Marchante E, Midgley SJ, Pauchard A, Rangan H, Richardson DM, Rinaudo T, Tassin J, Urgenson LS, von Maltitz GP, Zenni RD, Zylstra MJ (2011) Adoption, use and perception of Australian acacias around the world. Divers Distrib 17:822-836

Le Maitre DC, van Wilgen BW, Gelderblom CM, Bailey C, Chapman RA, Nel JA (2004) Invasive alien trees and water resources in South Africa: case studies of the costs and benefits of management. For Ecol Manag 160:143-159

Macdonald IAW (1983) Alien trees, shrubs and creepers invading indigenous vegetation in the Hluhluwe-Umfolozi game reserve complex in Natal. Bothalia 14:949-959

Mangla S, Callaway IM, Callaway RM (2008) Exotic invasive plant accumulates native soil pathogens which inhibit native plants. J Ecol 96:58-67

McFadyen REC (1989) Siam weed: a new threat to Australia's north. Plant Prot Q 4:3-7
McFadyen RC, Skarratt B (1996) Potential distribution of Chromolaena odorata (Siam weed) in Australia, Africa and Oceania. Agric Ecosyst Environ 59:89-96

McNeely JA (ed) (2001) Human dimensions of invasive alien species. IUCN, Gland Switzerland and Cambridge

McWilliam A (2000) A plague on your house? some impacts of Chromolaena odorata on Timorese livelihoods. Hum Ecol 28:451-469

Meijninger WML, Jarmain C (2014) Satellite-based annual evaporation estimates of invasive alien plant species and native vegetation in South Africa. Water SA 40:95-108

Mwangi E, Swallow B (2008) Prosopis juliflora invasion and rural livelihoods in the Lake Baringo area of Kenya. Conserv Soc 6:130-140

National Bureau of Statistics (NBS) and the Office of the Chief Government Statistician, Zanzibar (OCGS) (2013) 2012 Population and housing census: population distribution by administrative unite; key findings. NBS and OCGS, Dar es Salaam

Novoa A, Kaplan H, Wilson JRU, Richardson DM (2016) Resolving a prickly situation: involving stakeholders in invasive cactus management in South Africa. Environ Manage 57:998-1008

Pejchar L, Mooney H (2009) Invasive species, ecosystem services and human well-being. Trends Ecol Evol 24:497-504

Pimentel D (2002) Biological invasions: economic and environmental costs of alien plant, animal and microbe species. CRC Press, New York

Pimentel D, Lach L, Zuniga R, Morrison D (2001) Environmental and economic costs associated with non-indigenous species in the United States. Bioscience 50:53-64

Pyšek P, Richardson DM, Rejmánek M, Webster GL, Williamson M, Kirschner J (2004) Alien plants in checklists and floras: towards better communication between taxonomists and ecologists. Taxon 53:131-143

Rai RK, Scarborough H, Subedi N, Lamichhane B (2012) Invasive plants-do they devastate or diversify rural livelihoods? rural farmers' perception of three invasive plants in Nepal. J Nat Conserv 20:170-176

Raimundo RLG, Fonseca RL, Schachetti-Pereira R, Peterson AT, Lewinsohn TM (2007) Native and exotic distribution of Siamweed (Chromolaena odorata) modelled using the genetic algorithm for rule-set production. Weed Sci 55:41-48

Regional Commissioners Office (2013) Mara region investment profile. Regional Commissioners Office, Musoma

Rejmánek M, Richardson DM (2013) Trees and shrubs as invasive alien species - 2013 update of the global database. Divers Distrib 19:1093-1094. doi:10.1111/ddi.12075

Rejmánek M, Le Roux JJ, Huntley BJ, Richardson DM (2016) Rapid assessment survey of the invasive plant species in western Angola. Afr J Ecol. doi:10.1111/aje.12315(in press)

Sakuntaladewi N, Sumarhani, Suharti S, Widiarti A, Heriyanto NM, Djaenudin D (2016) Socio-economic impacts of Chromolaena odorata on communities around Merapi mountain national park, Indonesia, UNEP/GEF Project Fund No. 0515 unpublished report

Shackleton CM, McGarry D, Fourie S, Gambiza J, Shackleton SE, Fabricius C (2007) Assessing the effect of invasive alien species on rural livelihoods: case examples and a framework from South Africa. Hum Ecol 35:113-127 
Shackleton RT, Le Maitre DC, Richardson DM, van Wilgen BW (2015) Use of non-timber forest products from invasive alien Prosopis species (mesquite) and native trees in South Africa: implications for management. For Ecosys 2:16. doi:10.1186/s40663-015-0040-9

Simberloff D, Martin JL, Genovesi P, Maris V, Wardle DA, Aronson J, Courchamp F, Galil B, García-Berthou E, Pascal M, Pyšek P, Sousa R, Tabacchi E, Vilá M (2013) Impacts of biological invasions. What's what and the way forward. Trends Ecol Evol 28:58-66

Sundaram B, Krishanan S, Hiremath A, Joseph G (2012) Ecology and impacts of the invasive species, Lantana camara, in a social-ecological system in South India: perspectives from local knowledge. Hum Ecol 40:931-942

Tamado T, Milberg P (2000) Weed flora in arable fields of eastern Ethiopia with emphasis on the occurrence of Parthenium hysterophorus. Weed Res 40:507-521

Te Beest M, Cromsigt PGM, Ngobese J, Olff H (2012) Managing invasion at the cost of native habitat? An experimental test of the impact of fire on the invasion of Chromolaena odorata in a South African savanna. Biol Invasion 14:607-618

Te Beest M, Esler KJ, Richardson DM (2015) Linking functional traits to impacts of invasive plant species: a case study. Plant Ecol 216:293-305

Timbilla JA, Zachariades C, Braimah H (2003) Biological control and management of the alien invasive shrub, Chromolaena odorata in Africa. In: Neuenschwander P, Borgemeister C, Langewald $\mathrm{J}$ (eds) Biological control in IPM systems in Africa. CABI, London, pp 145-160

Uyi OO, Igbinosa IB (2013) The status of Chromolaena odorata and its biocontrol in West Africa. In: Zachariades C, Strathie LW, Day MD, Muniappan R (eds) Proceedings of the eighth international workshop on biological control and management of Chromolaena odorata and other Eupatorieae, Nairobi. ARC-PPRI, Pretoria, 1-2 Nov 2010, pp 86-98

van Wilgen BW, Richardson DM (2014) Managing invasive alien trees: challenges and trade-offs. Biol Invasions 16:721-734

van Wilgen BW, Dyer C, Hoffmann JH, Ivey P, Le Maitre DC, Moore JL, Richardson DM, Rouget M, Wannenburgh A,
Wilson JRU (2011) National-scale strategic approaches for managing introduced plants: insights from Australian acacias in South Africa. Divers Distrib 17:1060-1075

Waterhouse DF (1993) The major arthropod pests and weeds of agriculture in Southeast Asia: distribution, importance and origin. Australian Centre for International Agricultural Research, Canberra, p 141

Waterhouse DF (1994) Biological control of weeds: southeast Asian prospects. ACIAR Monogr 26:1-302

Wilson C, Mudita W (2000) Fire and weeds: interactions and management implications. ACIAR Proceedings

Winston RL, Schwarzländer M, Hinz HL, Day MD, Cock MJW, Julien MH (eds.) (2014) Biological control of weeds: A world catalogue of agents and their target weeds $\left(5^{\text {th }}\right.$ edn.) USDA forest service, Forest Health Technology Enterprise Team, Morgantown, FHTET-2014-04, pp 838

Witkowski ETF (2002). Invasion intensity and regeneration potential of the non-native invasive plant Chromolaena odorata at St Lucia, South Africa. In: Zachariades C, Muniappan R, Strathie LW (eds) Proceedings of the fifth international workshop on biological control and management of Chromolaena odorata, ARC-Plant Protection Research Institute, Pretoria, 106-117

Woodall SL (1981) Evapotranspiration and melaleuca. In: Geiger RK (ed) Proceedings of Melaleuca symposium, Florida division of forestry, Tallahassee, p 23-38

Zachariades C, Strathie LW (2006) Biocontrol of chromolaena in South Africa; recent activities in research and implementation. Biocon News Inf 27:10-15

Zachariades C, Day M, Muniappan R, Reddy GVP (2009) Chromolaena odorata (L.) King and Robinson (Asteraceae). In: Muniappan R, Reddy GVP, Raman A (eds) Biological control of tropical weeds using arthropods. Cambridge University Press, Cambridge, pp 130-162

Zachariades C, Janse van Rensburg S, Witt ABR (2013) Recent spread and new records of Chromolaena odorata in Africa. In: Zacharides C, Strathie LW, Day MD, Muniappan R (eds) Proceedings of the eighth workshop on biological control and management of Chromolaena odorata and other Eupatorieae, Nairobi. ARC-PPRI, Pretoria, 1-2 November 2010, pp 20-27 